【諭文】

UDC : 72.03:72.071.1(P)
Journal of Architecture Planning and Environmental Engineering

(Transactions of AIJ) No. 375, May, 1987

\title{
THE MULTIPLE CHARACTER OF ANDREA PALLADIO
}

\author{
by SHINJIRO KIRISHIKI*, Member of A. I. J.
}

\section{Introduction}

More than seven hundred papers and books have been written on and about Andrea Palladio (1508-80). ${ }^{1)}$ This is of course mainly due to the everlasting popularity of the Vicentine architect, whose unparalleled influence has now proved to be world-wide and was sometimes named Palladianism, an honorable term hardly allowed to even the greatest of architectural geniuses.

Nevertheless, the remarkable quantity of Palladian literature can not be explained merely by the popularity of the architect. The fundamental reason why so many arguments were raised and still being raised is simply that Palladio was and still is an enigma, a person who had left insoluble problems in many ways. Every student of Palladio must have an experience of having tried to confirm some minor datum about the architect in vain. Whether it was about his personal history, dates of his buildings, drawings, manuscripts, or travels, one can seldom be certain about all the details without any reservations. It is no exaggeration to say that almost all Palladian data are only presumptive.

That Palladio was an ardent classicist is well-known. But, without doubt, he belonged to the full-blooded Mannerist generation and was very active in the high time of the ltalian Mannerism. And, no one, if he admits that Michelangelo was "the father of the Baroque," can deny Palladio was also one of the forerunners of this anti-classical movement. In fact, any architectural historian who is writing about the sixteenth century Italian architecture must feel disconcerted about the historical evaluation and exact location of the architect.

Eventually, most historians were obliged to put Palladio into a position, unavoidably according to the chronological order, for instance, just after Michelangelo or Vignola, or, simply at the end of the long list of the sixteenth century architects as a local architect of specific importance. Many other questions about Palladio are either very hard to reply or nearly impossible to answer. Was Palladio an honest man, or a complete liar? Was he really religious or heretic? Was he a faithful follower of Vitruvius, or a revolutionist? The present paper is to analyse the inapprehensible character of the Vicentine architect and clarify the long-suspended enigma of Andrea Palladio.

\section{Unparalleled Multiplicity as an Renaissance Architect}

\section{(1) Palladio as a Classicist}

There is no denying that almost all the architects of the Renaissance were worshipers of the antiquity. But, the antiquity worship was the irresistible fashion of the time, and therefore, the degree of real faithfulness to the antiquity on the part of an architect largely depends upon his personality and taste. Palladio had conducted his antiquarian studies for more than thirty years, first under the guidance of Giangiorgio Trissino (1478-1550). and later under that of Daniele Barbaro (1513-70). Trissino and Barbaro were the most prominent figures in classical studies in the sixteenth century Veneto; Palladio was chosen by the first as a promising youth for the ideal architect, but in turn had chosen the second as an ideal tutor to further his classical studies. No one can imagine better teachers, and Palladio's classical education was as complete as one can possibly expect from a master-mason who was initiated for classical studies in his mid-thirties.

From his Four Books, we are able to know Palladio's favorite authors were Herodotus, Caesar, Livy, Pliny, Tacitus and Plutarch. We are informed also from his Antichita di Roma that he collected his materials mainly from Dionysius of Haricarnassus, Appianos of Alexandria, Valerius Maximus, Eutropius, etc. No other architect, except Leon Battista Alberti, would have conducted his classical studies to such an extent. Here was a really serious student of classical history and not an architect merely pretending to be a classicist.

\footnotetext{
* Professor, D. Eng., Department of Architecture, Faculty of Technology, Tokyo Metropolitan University.

(Manuscript received October 7, 1986) 
Palladio was so much impressed by the magnificence, grandeur and durability of Roman architecture during his five visits to Rome, that he had become not only an great admirer of the Roman architecture, but also a worshiper of the virtues of the ancient Romans themselves. He may have tried to be an ancient in his innermost life.

(2) Palladio as an Archaeologist

Although we can not believe all of what Palladio told of his extensive journeys and measurements of ancient monuments, ${ }^{2)}$ we are able at least to rely on his studies on ancient buildings within the city of Rome and its environs. The significant point is that Palladio had realized even the minutest measurements could not carry one to the true understanding of ancient architecture, and therefore, he transformed himself from a mere researcher and surveyor into a restorer-archaeologist. This makes the Fourth Book an unique collection of restored ancient monuments. He is said to have learned this method of archaeological research from Pirro Ligorio, ${ }^{3)}$ but his method is so typically Palladian that we can not help believing Palladio simpy reaffirmed the validity of his own method which was based upon his personal experiences and reasoning.

Although some of his drawings are the only extant records left about some ancient buildings which were since destroyed, ${ }^{4)}$ his drawings of ancient buildings are not the restoration drawings in the modern sense, but imaginary projections of the ancient monuments as he liked them to have been. The restoration plans and elevations of ideal Greek and Roman piazzas in the Third Book clearly prove this.

(3) Palladio as a Mannerist

Judging either from his life span, or from the names of the architects who had close contacts with him, Palladio was active amidst the turmoil of Mannerism. Jacopo Sansovino, Sebastiano Serlio, Michele Sanmicheli, and Giulio Romano, all of whom Palladio had got to know through the building of the Vicentine Basilica, were more or less the representatives of Italian Mannerism. In Rome, Palladio learned much from the Mannerist details of Michelangelo. Except for the architecture of villas, Palladio was definitely under the strong influences of these architects.

Palladio's architectural works which bear his Mannerism most clearly are : Basilica Palladiana (Vicenza), Villa Pisani (Bagnolo di Lonigo), Palazzo Thiene (Vicenza), Palazzo Iseppo-Porto (Vicenza), Villa Poiana (Poiana Maggiore), Palazzo Antonini (Udine), Villa Barbaro (Maser), Palazzo Bonin-Longare (Vicenza), Palazzo Valmarana (Vicenza), Loggia del Capitaniato (Vicenza), Palazzo Barbarano (Vicenza), Palazzo Porto-Breganze (Vicenza), Villa Sarego (Santa Sofia di Pedemonte), Tempietto Barbaro (Maser). ${ }^{5)}$ You may notice that most of them are public buildings and private town houses, and only a few villas are included.

(4) Palladio as a Pioneer of the Baroque

Palladio, in parallel with Michelangelo, distinguished himself as a pioneer of the Baroque composition by using colossal orders, villa planning in three parts, five parts and seven parts, with advanced and receded ends, curved porticos, and a line of ornamental statues, as well as putting predominating emphasis on the central axis.

Venetian Baroque architecture, represented by Longhena's Santa Maria della Salute, and Roman Baroque architecture, represented by Bernini's colonnaded piazza of St. Peter's and curved walls of Sant' Andrea al Quirinale were derived directly from Palladio's ideas. ${ }^{6)}$

(5) Palladio as a Forerunner of Neo-classicism

Although there once was published a paper entitled "Why Palladio was not Neo-classicist," ") it is an undeniable fact that Palladio can be regarded as the pioneer of the Neo-classicism. This is an inevitable conclusion, if the highlights of Palladianism in Northern Italy and England should be understood as the reflections of strong anti-Baroque feeling in these areas. ${ }^{8)}$

Even when some archaeological knowledge of ancient architecture became indispensable assets for architects, Palladio was still recognized as the foremost Renaissance architect who could have approached the most profound of the principles of ancient architecture. Deification of Andrea Palladio had already started by such admirers as Francesco Muttoni (1669-1747), Tommaso Temanza (1705-89) and Francesco Milizia (1725-98). ${ }^{9}$ How could these men make Mannerist Palladio or Baroque Palladio a pure and genuine guardian angel of classicism? They simply had ignored and neglected such works that seemed most unsuitable to Classicist Palladio.

(6) Palladio as a Forerunner of the Picturesque 
Palladio was also a pioneer of the Picturesque in architecture. Uniting a work of architecture and landscape to make up a picturesque composition has been a sound and legitimate way of architectural design, but there had scarcely been any Renaissance architects who had better hands in this field than Palladio's probably because most of the Renaissance buildings were packed into a high-density city blocks.

Palladio, one of the foremost architects of villas, took the picturesque effect for granted. ${ }^{10)}$ Villa Rotonda was so much welcomed because it was not only the zenith of Palladian Neo-classicism but also the peak of the Picturesque villas. San Giorgio Maggiore and il Redentore in Venice are, of course, among the best of picturesque churches in history.

\section{(7) Palladio as a Formalist}

No one can deny that Palladio was a great formalist in the sense that he persisted, wherever possible, the principles of the completely symmetrical plan, of the identical plan for every floor, and of the three-dimensional harmonious ratios of major rooms; the degree of his persistence was remarkable even among the Renaissance architects. ${ }^{11)}$ And moreover, Palladio preferred porticos, pediments, series of statues pompously standing on the balustrades, mainly for the effect reminiscent of the magnificence of ancient Rome.

It is also evident that this strong formalism of Palladio's had guaranteed his everlasting popularity, because it was due to this formalism of his that the Palladian method was very easy to understand, very interesting to apply, and fascinating to see the realization, and above all, very difficult to fail.

\section{Palladio as a Pioneer of Architectural Modernism}

\section{(8) Palladio as a Functionalist}

Functionalism is not a feature peculiar to the Modern Movement. Functionalism in architecture is as ancient as architecture itself, and Modern Functionalism can be defined as the functionalism putting specific emphasis on economy, efficiency and explicability. And, this attitude was most conspicuous in Palladio of all the Renaissance architects. Palladio repeated in his Four Books his special concerns about convenience and economy. ${ }^{12)} \mathrm{He}$ persisted his pragmatic attitude in the disposition of major rooms, and declared that the purpose of architectural design was to consider the client's benefits wherever possible. Palladio's economic functionalism was best revealed in his almost standardized method of stuccoed brick construction. ${ }^{13)}$ He curtailed the use of stones to the minimum, employing them only for the bases, capitals, entablatures and dressings of doors and windows. Moreover, especially in his early works, he frequently tried to simplify the classical orders and other classical motives. ${ }^{14)}$

(9) Palladio as a Structural Rationalist

Palladio, having been a craftsman. highly evaluated the structural soundness and durability. He recommended to use the best materials, fixed the safety ratios for wall-and-window relations, adopted perfectly symmetrical planning, inserted mezzanine floors, made light-weight stuccoed vaults of canes, gave appropriate projection of details, and was very careful about logical disposition of beams and joists. He tried to avoid any contradictions in his construction system. He can safely be called the structural rationalist in the similar sense that three centuries later Eugène Emanuele Viollet-Ie-Duc was called the rationalist in his theoretical studies and restoration works on Gothic monuments of France.

(10) Palladio as a Creative Structural Engineer :

Practical considerations from the engineer's point of view is a remarkable characteristic of Palladio 's Four Books. Above all, the trussed bridges illustrated in the Third Book have been recognized by most of the historians of technology as the earliest known examples of wooden trusses. ${ }^{15)}$ It is, however, too much to say that Palladio was the inventor of trussed structures, since ancient Roman architects and engineers definitely knew both wooden and metal trusses, and bracing members seem to have been quite common in the Roman and Renaissance bridges and other structures. We ought to pay attention rather to the fact that peculiar metal joints applied to the trussed wooden bridges might be the great invention of Palladio. In any way, he must have done a considerable number of experiments and trials before he put them into practice.

Also epoch-making was his adoption of projection drawings throughout the Four Books. We know Vignola used the method in his drawings of orders, but Palladio applied it also to the drawings of buildings, of which no examples were included in Vignola's Regole. These two achievements may qualify him as one of the most distinguished 
engineers of all the times.

\section{Palladio as an Writer and Illustrator}

(11) Palladio as a Writer

The charm of Palladio's Four books lies in their profuse illustrations as well as their concise texts. Goethe made a comment on Palladio in his Italian Journey, saying 'he is a man of few words; but his words are all solemn. ' Goethe also wrote to Charlotte von Stein about the Four Books, "This is also a great work as a book. ${ }^{16)}$

Although some may complain about the poverty of Palladio's vocabulary, or his frequent vagueness in some important passages, the extraordinary success of the Four Books itself proved his prominence as a writer. The glamour of the text of the Four Boods seems to have been enhanced by an appropriate quantity of moderate pedantry, of technical and historical episodes and Palladio's very personal recollections.

(12) Palladio as an Illustrator

Palladio's ability as a graphic designer was pertinently pointed out by Mr. Kazutoshi Morita. ${ }^{17)}$ Each page of the Four Books was carefully and elaborately designed to give the reader a compact and delightful impression.

He made the printed area as large as possible, leaving minimized margins. He put the drawings of the First and Fourth Books in rectangular frames, while the drawings of the Second Book are mostly shown without frames. The Third Book contains a mixture of both the framed and non-framed drawings. Palladio was so much absorbed in making a fine layout, he sometimes omitted a part of the explanation. ${ }^{18)}$

(13) Palladio as an Educator

Palladio's Four Books are among the best text books of architecture ever written. Assuming his readers be everyone of every class, he included among his presumptive readers kings and princes and other aristocratic patrons, men of the Church, intellectual burghers who could have voices in the matters of public buildings, artists and craftsmen in other fields, as well as architects and men of building trades. ${ }^{19)}$ This, indeed, is an outstanading feature of the Four Books, as compared with other great treastises of the Renaissance, such as Alberti's, Serlio's and Vignola's. The wider selection of readers came from his sincere wish for the improvement of architecture through the cooperation of all those who participated in production of a building.

Such a great caliber of social consciousness seems to have yet been extremely rare among the artists and architects of the Renaissance, and bears witness to the fact that Palladio was a born educator of the highest rank.

\section{Palladio as a Human Specimen}

Although there exists something very intricate and mysterious in Palladio's character that can not easily be reasoned away, we still are able to take hold of a few typical human touches in his personality.

(14) Palladio as an Idealist

This may be the characteristic most commonly found among architects of any period. Palladio, however, was definitely an extreme case as a formalist and structural rationalist, to such an extent that can be called stubbornness, or obstinacy.

A lifelong pursuer of the formal beauty and rational structure, Palladio experienced a number of frustrations and had left a number of buildings unfinished. Moreover, he sometimes committed most elementary faults, simply because he occasionally attached too much importance to either formalities or theories than to conventions and experiences. ${ }^{20)}$

(15) Palladio as a Freethinker

Although Palladio frequently mentions the name of God in the Four Books, no one would be deceived by his display. Palladio's real sympathy with the divine was definitely pagan; how he seems to be joyous and natural when he speak about pagan gods and goddesses. Heretics were still the objects of interrogation and persecution in the sixteenth century. And therefore, he called the Christian God from time to time in order not to be accused by the Church and his religious patrons. ${ }^{21)}$

The sixteenth century Veneto produced a number of intellectuals who leant toward Protestantism, but Palladio had no indication of such an inclination. He seems to have been more at home with pagan gods and heroes.

Palladio regarded religion as an essential factor in social life. ${ }^{22)}$ probably because he hated social disorder and believed in the civilizing effect of religions. He was zealous for the strict rules of conducts among the citizens. He 
must have some repulsive feeling against either the fervency of the Reformation, or the frenzy of the Counter-Reformation. In short, Palladio's religious attitude can be defined as that which was not dissimilar to the late eighteenth and early nineteenth century freethinkers that had strong inclinations toward Paganism.

(16) Palladio as a Evasive Concealer

In spite of his superficial amiableness and sociability, Palladio, in his innermost life, seems to have been a misanthropist, who usually held himself in proud solitude, but frequently fell into an extreme self-abhorrence. ${ }^{23)} \mathrm{He}$ was sincere and honest as a practicing architect, but too positive and stubborn in keeping his personal concepts. Especially in his latest years and during the time immediately before and after his death, there were no traces of his having been loved or respected. ${ }^{24)}$ It was an extraordinary fact for such a well-known and successful architect as Palladio that the cause and place of his death were unknown, and moreover, the date of his funeral and the place of burial uncertain.

The amazing lack of documents and records about Palladio's personal life will be another incomprehensible fact, if Palladio himself did not possess a strong inclination of secluding himself from the world and of concealing (but not entirely) most of the traces of his private life. ${ }^{25)} \mathrm{He}$ wanted to be famous and immortal as an artist, but he did not want his private matters to be publicized. Within the outer skin of a typical Renaissance man who aspired after honor and fame, there was a very modern personality that might have suffered severely from neurotic disturbances.

\section{Conclusion}

Pursuing the inapprehensible character of Andrea Palladio, we now have got sixteen remarkable characteristics of the architect. Palladio was first of all ( 1 ) a foremost Classicist and ( 2 ) archaeologist, but he was also ( 3 ) one of the genuine Mannerists, the avant-garde of the times. Moreover, we can safely call him ( 4 ) a pioneer of the Baroque, ( 5 ) a pioneer of the Neo-classicism, and even (6) a pioneer of the Picturesque. As an artist, no one can be comparable with him as ( 7 ) an absolute formalist.

Palladio was actually the first Modernist. He was ( 8 ) an unmistakable functionalist, ( 9 ) structural rationalist, and (10) creative engineer. No one can deprive Palladio of the above-mentioned ten characteristics, and such incredible multiplicity was the main cause why Palladio could not be easily classified and properly located in the architectural history.

Palladio's Four Books proved that he was distinguished as (11) a writer, (12) illustrator, and (13) educator. Palladio, as a man, was (14) a very obstinate idealist, and (13) a freethinker aspiring towards pagan virtues. The most conspicuous feature of Palladio's personality, however, was his strong inclination to be (16) a great master of evasion and concealment of all the times, He wholeheartedly wished fame and honor, but at the same time he wanted his personal affairs not to be revealed even to his most intimate friends. And, it is this contradictorily multiple character of his, though perhaps very fascinating as a human specimen, that has made biographical studies of Palladio extremely difficult.

\section{Notes and References}

1) Lionello Puppi compiled a chronological bibliography of Palladio up to 1973, including more than seven hundred papers and books, more than half of which were published sined 1960. Puppi, Lionello, Andrea Palladio, Electa Editrice, Venezia, 1973 ; English edition, New York Graphic Society, 1975, General Bibliography, pp. 441-453.

2) Some of the drawings of ancient buildings drawn by Palladio do not appear to have been measured by him ; many seem to have been redrawn from the drawings and sketches by other architects and simply attached with Vicentine measures. Some were partly redrawn, according to his own measurements. Some of Palladio's drawings are completely different from the existing monuments in certain important points, and therefore, it is self-evident that Palladio himself did not see these buildings carefully enough, not to speak of measurements, but borrowed incorrect drawings of other architects : for example, of Temple of Vesta at Tivoli (Fourth Book, Chap. 23) and Temple of Minerva in Assisi (Fourth Book, Chap. 26).

3) Ligorio published his Il libro delle antichita di Roma in 1553, and Palladio published his Antichita di Rome the following year. Ackerman, James S., Palladio. Panguin Books, Harmondsworth, 1966, p. 27.

4) For example, Porta Leoni in Verona (RIBA XII 19r, 20r, 18v, 19v, 20v), and Temple of Serapis in Rome (Fourth Book, Chap. 12).

5) The present author counts the Basilica Palladiana among the Mannerist works of Palladio, since he thinks the Serliana was a typically Mannerist motif. Serliana was of the ancient origin and can properly be classified as one of the motives of the Baroque phase of ancient Roman architecture. Kirishiki, Shinjiro, On Ancient Origins of the Palladian Motive, Papers and 
Reports for the Annual Meeting of the Kanto Branch of the Architectural Institute of Japan, July, 1986.

6) Wittkower, Rudolf, Palladio's Influence on Venetian Religious Architecture, and Palladio and Bernini, Bollettino del CISA, V, 1963 and W, 1966 ; later included in his 'Palladio and English Palladianism', London, 1974, pp. 11-22, and pp. 25-38.

7) For example, see Brandi, Cesare, Perché il Palladio non fu neaclassico, in 'Essays in the History of Architecture, Presented to Rudolf Wittkower', Phaidon Press, London 1967, pp. 116-121.

8) Palladio's influence on villa architecture in Northern Italy began to appear already in his lifetime, for instance, in Vincenzo Scamozzi's villas. Palladio was widely imitated during the late sixteenth and early seventeenth century, so that they might attract attentions of foreign architects who happened to travel in North Italy. Not only in Italy but also in most countries where his influences were prominent, he was respected mainly as the representative of true and sincere classicism. See Palladio: La sua ereditá nel mondo, Electa Editorice, Venezia, 1980.

9) Fukuda Seiken, Palladio, Kajima Shuppankai, Tokyo, 1979, pp. 51-52.

10) Palladio's keen interest in landscape is clearly shown in some of the descriptions of environments of his villas in the Second Book.

11) Palladio even transformed some buildings of irregular plans into regular forms; for example, Palazzo Valmarana, Vicenza (Second Book, Chap. 3, p.16) and Basilica Palladiana, Vicenza (Third Book, Chap. 20, p.42). It seems to the present author very characteristic of Palladio's formalism that he completely erased from the Basilica plan the irregularity which was the greatest reason to make use of the Serliana.

12) For instance, First Book, Preface to the Readers, p. 5, and Chap. 1, pp.6-7; Second Book, Chap.2. p. 3, and Chap. 12, p. 45.

13) Among Palladio's buildings, only the two-storied arcades of Basilica Palladiana in Vicenza and the façades of three Venetian churches are built of stone. All others are stuccoed brick buildings.

14) For example, the rear front of Villa Godi, Lonedo di Lugo Vicentino; façade of Villa Saraceno, Finale di Agugliaro ; the entrance of Villa Poiana, Poiana Maggiore. Palladio sometimes omitted the diminution of column and pilaster shafts, as in Villa Thiene, Quinto Vicentino.

15) See, for example, Straub, Hans, A History of Civil Engineering: An Outline from Ancient to Modern Times. The MIT Press, 1964, p. 202, or Cowan, Henry J., An Historical Outline of Architectural Science. Elsevier, Amsterdam-London-New York, 1966 , p. 48.

16) Goethe, Johann Wolfgang von, Italienische Reise, I, 1816, Oct. 10, 1786, and Tagebücher, S. 128.

17) Morita Kazutoshi, Notes sur Palladio, II, Villa Almerico. La Rotonda (suite), QUADRATO, II, Bunka Gakuin School of Architecture, Tokyo, July, 1980, pp. 22-35.

18) See Fourth Book, p. 16, p. 74, and p. 89.

19) First Book, Preface to the Readers, p. 5 ; Third Book, Preface to the Readers, pp. 5-6 ; Fourth Book, Preface to the Readers, p. 3.

20) Palladio selected very hard stones for the Basilica Palladiana and had them carried from the quarries at Piovene, twenty-five kilometers NNW of Vicenza. Unfortunately, however, the stone, though very hard, has now proved to be too brittle, and not so durable as he had expected. At the Convent of the Carità in Venice, Palladio built a flat roof over the Corinthian atrium. This was a brick-paved terrace made on the plank floor and immediately there were leaks in the roof. Palladio was forced to repair the roof at his own expense in August 1569 and again in June 1570. When Inigo Jones visited the Convent in the early seventeenth century, the roof was still leaking and was covered by another roof supported by pilasters. See Barbieri, Franco, The Basilica of Andrea Palladio (CORPUS PALLADIANUM II). The Pennsylvania State University Press, University Park \& London, 1970 ; and Allsopp, Bruce, Inigo Jones on Palladio, 2 vols., Worcester College, Oxford, 1970, Vol. I, p. 25, 11.4-7.

21) For example, Fourth Book, Chap.1, p.5, and Chap. 2, p. 6.

22) Third Book, Preface to the Readers, p. 6.

23) Palladio frequently assumed strange attitudes towards familiar patrons and friends. For instance, he mistook the name of the client he could never forget (Girolamo Chiericati, Second Book, Chap. 3, p. 6). Sometimes, he deliberately ignored the mural paintings by such a famous artist as Paolo Veronese (Villa Barbaro, Second Book, Chap. 14, p. 51).

24) Palladio is said to have died on August 19, 1580, but the cause and place of his death are unknown. It was told his body was buried at Santa Corona in Vicenza, but there is no church record about htis burial. On August 15, 1845, the so-called relics of Palladio was moved to the city cemetery and the so-called tomb of Palladio was built, but there is no positive evidence that the relics were really those of Palladio's.

25) There are hardly any letters and diaries left by Palladio. Most of the records concerning with him are those with which he was associated as a witness, observer, or recipient. And therefore, the records about his activities, and dates of designing, beginning and completion of a building, are mostly suppositions accumulated by untiring efforts of a number of Palladian scholars during four hundred years since his death. One can dare to speculate that Palladio may have tried every effort to conceal exact records about himself. 


\section{パラーディオの多面泾（梗概）}

\section{1. 序 論}

パラーディオ（1508-80）に関して，これまでに 700 篇を越える論文・研究書が書かれてきた。これは，もち ろん主としてパラーディオの永続的な人気や影鳘力によ るものであるが，それだけでは説明しきれない。これだ けの議論がかつてなされ，今も行われ続けている最大の 原因は，バラーディオ自身が多大の疑問点を残した譢の 人物であったことによる。

パラーディオが熱烈な古典主義者であったことはよく 知られている。しかし, 彼が全盛期のマニエリスムの渦 中にあって成功した建築家だったことも確かである。ま た, バラーディオがバロック的構成の先駆者の一人で あったことも否定できない。パラーディオとは果たして いかなる建築家なのか。その他, 幾多の疑問が山積して いる。

本論は, この捉えがたいパラーディオの建築家および 人間としての資質と性格を捕捉し, 上記の問題点の解明 に寄与しょうとするものである。

\section{2. ルネッサンス進筑家としての比頻ない多面性}

（1）古典主義者としてのパラーディオ パラーディオは壮年の頃から，トリッシノ，コルナー ロ, バールバロといった当時の北イタリアを代表する ヒューマニストたちの知遇を得, ヴィトルヴィウスやア ルベルティの研究ばかりでなく, 本格的な古代史研究を 行ない, 前後五回の口ーマ旅行を含む調査旅行では, 口ー マ建築の偉容と耐久力に警嘆し，終生の模範とした。そ のローマ文化への傾倒は, 古代ローマ人の美徳の崇拝に まで進んでゆき，その心酔の度合は，通例の予測をはる 加に上迴るものとなっていた。

(2) 考古学者としてのパラーディオ

パラーディオがその『建築四書』のなかで誇っている ような広笣な調査旅行を実際に行ったとは思われない が, 熱心な調査の結果, 遣跡の実測が必ずしも古代建築 の全貌の理解につながらないことを语って、ついに復原 考古学者となる。これは, 『四書』の第三書・第四書の 表。

日本建築学会関東支部研究報告集（昭和 60 年 7 月）に一部発

東京都立大学 教授・工博

(昭和 61 年 10 月 7 日原稿受理)

$-132-$
正会員桐敷 真 次 郎*

著るしい特色を形づくっている。

（3）マニエリスタとしてのパラーディオ

作品上はもちろんのこと，年代的にみても，影響を受 けた周辺の建築家からみても，パラーディオは紛れもな いマニエリスタの一人であった。彼が純勒な古典主義の 権化のように思われてきたのは, まったく新古典主義者 たちの作為によるものである。パラーディオの作品で, そのマニエリスムが䫓著に現われているものは都市建築 に多く、ヴィッラは比較的少ない。

(4) バロックの先駆者としてのパラーディオ

大オーダーの使用, ヴィッラ主館の三部構成, さらに 翼屋を加えた五部構成あるいは七部構成, 建物両端部の 前進と後退, カーブした列柱廊, 支毁的な中心軸線の強 調, 立像装飾, 板状バットレスの活用などにより, パラー ディオは, 明らかにミケランジェロと並んでバロック的 構成の先駆者となっている。

（5）新古典主義の先駆者としてのパラーディオ

「パラーディオはなぜ新古典主義者でないか」という ような論文もあるが，北イタリアとイギリスにおけるパ ラーディオ主義の隆盛, アメリカ・ロシアへのパラー ディオ主義の伝播・普及を考えれば，彼が新古典主義の 先駆者とみなされていたことは疑う余地がない。パラー ディオは列柱と壁体の対照を好み，これが新古典主義者 たちから神格化される端緒となった。他方, 新古典主義 者たちは, パラーディオの作品のうち，マニエリスムと バロック臭の濃厚なものは除外し無視したのである。

(6) ピクチャレスクの先駆者としてのパラーディオ ルネッサンス建築が主として密集した都市建築として 発展したため, 絵画的効果を自由につくり出すことは難 かしかった。パラーディオはヴィッラを得意とする建築 家として, 風景と建築の結合を当然のこととした。ヴィッ ラ・ロトンダは, パラーデイオ式新古典主義の頂点であ ると同時に, ピクチャレスク・ヴィッラの理想でもあっ たから，あれほどもてはやされたのである。

（7）形式主義者としてのパラーディオ

完全対称形の平面に加えて, 各層同一平面, 主要室 の三次元的比例の固執は，パラーディオの建築計画の著 るしい特色をなしている。列柱廊，ペジメント，立像装 飾の汎用，ローマ的な壮大趣哧と合せて，パラーディオ 
はきわめて強度のフォーマリストであった。しかし，こ のフォーマリズムがパラーディオの永続的人気の源泉と なったことも明らかで，それは，誰にもわかりやすく， パズルを解く面白さと楽しさを設計者に与え，しかも失 敗するおそれがほとんぼなかったからである。

3. 近代主義者としてのパラーディオ

（8）機能主義者パラーディオ

パラーディオの『四書】には，使い勝手の便利と経費 の節約という観点が繰返し示され，各室の配置には徹底 した実利主義が見られ，建主の利益が最大の目的とされ ている。石造を避け，煉瓦造ストゥッコを標準工法とし， オーダーの簡略化をしばしば行っていることも，パラー ディオの経済的機能主義の表われである。

（9）構造合理主義者としてのパラーディオ

パラーディオは, 構造の健全さと耐久性を最も重んじ た。最良の材料，開口部に関する構造規定，完全対称形 平面の採用, 中二階の扦入，籐の骨組の軽量ヴォールト 天井, 細部の突出量, 梁の配置に至るまで, 一貫した構 造合理主義がみられる。

(10）エンジニアとしてのパラーディオ

第三書の各種トラス橋のデザインは，ほとんどの技術 史書に最古の実例として取り上げられている。パラ一 ディオ自身がこれらのトラスを発明したとは考えられな いが，接合金具の工夫には注目すべきものがあり，やは り傑出したエンジニアに数えられてよい。また，縮尺つ き正投象図面の一貫した採用も，当時として画期的だっ た。

\section{4. 著述家・イラストレーターとしてのパラーディオ}

(11） 著述家としてのパラーディオ

「建築四書」の魅力は，その豊富な図版を本文の簡潔 さにあるといわれた。ゲーテも「彼は口数は少ないが, その言葉はすべて重々しい」「これは書物としても偉大 な作品です」と評している。用語の分困とか, 重要な箇 所におけるあいまいさなどの欠点があるにしても，『四 書」の異常な成功そのものが, パラーディオの著述家と しての卓抜さを示している。その魅力は, 適当な量のぺ ダントリー, 適切な量のエピソードと個人的コメントの 挿入によって高められている。

(12）イラストレーターとしてのパラーディオ

森田一敏氏が指摘されたように，『四書」のレイアウ トは，きわめて意識的に入念にデザインされている。用 紙いっぱいにとられた版面, 長方形の枠にきちんと図を 収めた第一書・第四書に対して，枠どりのない第二書， 両者を混じた第三書など，よく内容に即したレイアウト を施してあり，時にはレイアウトのために本文中の図版 説明の一部を省略しさえしている。

(13）教育家としてのパラーディオ
「建築四書」は，古今の最もすぐれた建築教本のひと つである。パラーディオは, 読者として, パトロンであ る貴族・教会から，知識階級，建築家，美術家，職人に 至るまで，すべての階層を想定していた。それは，彼が， 建築に関わるすべての人の協力による建築の質の向上を 心から願っていたためで，このような幅広い社会意識は 当時の建築家には稀有のものであり，パラーディオの教 㕕家としての天分を示している。

5. 人間典型としてのパラーディオ

（14）理想主義者パラーディオ

建築家としてのパラーディオは, 形式主義者・構造合 理主義者として頑ななまでに理想主義者であった。形式 美と合理性のあくなく追求者として一生を貫いたが，そ のために幾多の挫折を味わい,多数の未完作品を残した。 また時には，経験よりも形式と理論を重んじたため，き わめて初歩的な失敗を犯すこともあった。

（15）自由信仰家パラーディオ

パラーディオはしばしば神の名をロにするが，その信 仰の基調は完全に異教的である。パラーディオは，宗教 は社会生活に不可欠なものと考えていたが，パラーディ オにはプロテスタンティズムへの共感は全くなく，また 反宗教改革陣営への積極的参加も感じられない。結局, パラーディオの宗教的な態度は, 異教的な自由信仰家の それと認定できる。

（16）觬晦家パラーディオ

表面上の信心深さとやさしさは，パラーディオの内奥 とは一致せず，彼は基本的には孤独孤高の人間嫌いで， しばしば自己嫌悪に陥るようなタイプであった。建築家 としては律儀であったが, 妥協を拒む偏屈さが目立ち, 特に最晚年や死の前後には周囲から敬愛された形跡がま るでない。パラーディオの個人的生活に関する記録の驚 くべき欠如は, 彼自身の孤独癖と㗖烸趣味を想定しなけ ればとうてい理解できない。名誉と名声を熱望するルネ サンス人的外皮のなかに, 極度に神経症的な近代人が垣 間見られる。

6. 結 論

捉えがたいパラーディオの正体を追求して, 以上 16 の顕著な特性を得た。特に（1）から（10）までの特性 は,いすれも否定しがたい根據をもつものである。パラー ディオは，古今の建築家のなかでも並はずれた幅の広さ と複雑さをもった人物で, 建築家パラーディオの評価・ 分類・位置づけが容易でなかった理由は，まさにこの比 類のない多面性にあった。また人間としてのパラーディ オもきわめて複雑であり, 特に生まれながらの塪晦家と しての性格が, 建築家パラーディオの伝記的研究をはな はだしく困難なものにしてきた。 